\title{
Ecological and Ethnomedicinal Values of Sacred Plants in Some Major Temples of Bhopal, India
}

\author{
Aadil Mir ${ }^{1}$, Vipin Vyas ${ }^{2}$, Pradeep Shrivastava ${ }^{1}$, \\ Abhilasha Bhawsar ${ }^{1}$ and Manzoor Ahmad Bhat ${ }^{1 *}$ \\ ${ }^{1}$ Department of Environmental Sciences and Limnology, Barkatullah University, \\ Bhopal, India \\ ${ }^{2}$ Department of Biosciences, Barkatullah University, Bhopal, India \\ *Corresponding author
}

\section{A B S T R A C T}

\section{Keywords}

Sacred plants,

Ethnomedicinal,

Ecological,

Conservation

Article Info

Accepted:

12 December 2017

Available Online:

10 January 2018
The present research paper describes the sacred plants found in the vicinity of five major temples of Bhopal, India. In addition, the ethnomedicinal and ecological values of these plants were also reported. The information was obtained from priests and knowledgeable local people about the sacred value of plants associated with religious rituals. A total of 13 sacred plants species belonging to 10 families were identified during the survey. The study concludes that propagation of sacred plants contributes to the conservation of floral diversity. Thus, religious activities associated with sacred plants boosts up the protection and maintenance of the biodiversity.

\section{Introduction}

Plants are nature's major processors of solar energy which is essential for our existence. The ancient beliefs showed that there is significant relationship between human beings and plants. Plants have been traditionally considered sacred due to its close association with a deity. For example Bel tree (Aegle marmelos L.) is associated with Lord Shiva.

Sacred plants are considered to be incarnations or symbols of God or deities and therefore their worship became more common. They play a very important role in the myths and customs of India. Without the use of sacred plants and their products, the religious and cultural rituals are not completed (Pandey and Pandey, 2016).

The trend of sacred plant worshipping was also present during the Vedic period (Bhatla et al., 1984).

Furthermore, all people celebrate religious festivals with a scientific background and use one or several plant parts in their ceremonies (Bajpai et al., 2016). The various parts of 
plants have been used as a source of medicine by man from ancient to the modern era (Truyen et al., 2015). The ecological face of sacred plants or sacred groves lies in the fact that they serve as biological heritage and a system that has helped to preserve the representative genetic resources existing in the surrounding regions to conserve rich biological diversity.

\section{Materials and Methods}

Bhopal is the capital city of the Indian state, Madhya Pradesh. It is known as the city of lakes while it is also famous for old temples. The five major temples of Bhopal were surveyed for six months during July-Dec, 2016. The study includes Panchdev Durga temple, Hanuman Chamatkari temple, Birla temple, Gayatri temple and Guffa temple.

Frequent field trips were made to collect information about sacred plants in the premises of these temples and the collected plants were brought to the laboratory identified with the help of professionals/subject experts and available literature (Sivalingam et al., 2016).

At each temple the local people including, priests of the temples, knowledgeable local people and traditional healers were interacted to gather information about the sacred value and ethnomedicinal value of sacred plants ((Pandey and Pandey, 2016). The details of the temples are given below:

\section{Panchdev Durga temple}

The Panchdev Durga temple is located within the premises of Barkatullah University, Bhopal. Besides employees of the university, people from outside university campus also come to visit this temple. A number of different sacred plants are present in this temple.

\section{Hanuman Chamatkari temple}

Hanuman Chamatkari temple is also located within the premises of Barkatullah University. A good fencing is made around the temple and inside temple a deity of Hanuman is present. The temple is open early in the morning and in the evening for its devotees. A number of local people residing near the temple come to worship. During the survey, a number of different sacred plants were found in the premises of Hanuman chamatkari temple.

\section{Birla temple}

Birla temple is situated on the Arera Hills and is one of the famous temples of Bhopal. The temple is known as "Lakshmi Narayan Temple" or "Birla Mandir" as it is constructed by the well-known industrialist family, the Birla group. The temple is dedicated to Lakshmi, the Goddess of wealth and houses beautiful idols of Goddess Lakshmi and Lord Vishnu, along with the Lord Shiva and Parvati. The temple is open to all its devotees, irrespective of caste and creed. The entire temple is surrounded by beautiful lawns, fountains and numerous sacred, ornamental and flowering plants which give visitors a feeling of peace and tranquillity.

\section{Gayatri temple}

Gayatri temple is located in Maharana Pratap Nagar. The temple consists of a deity of Gayatri Mata and number of devotees visit temple every day. Many sacred plants are present in the premises of Gayatri temple.

\section{Gufa temple}

Gufa temple is situated in the outskirt of Bhopal at Lalghati near Idgah hill. Swami Narayan Dasji Maharaj established a Shiv temple in the cave, hence called as Gufa Mandir. The temple is very old and has large 
complex with many natural caves, houses beautiful idols of Goddess Durga, Lord Shiva, Ram Laxman, Sita and Hanuman. Every day large number of devotees from different parts of the world throng here to have darshan of the deities and experience spirituality.

\section{Results and Discussion}

The present study was carried out on five major temples of Bhopal. A total of 13 species of sacred plants belonging to 11 families were recorded during the study (Table 1). The information on sacred value, ethnomedicinal value and ecological value of plants recorded during the survey are documented below:

\section{Aegle marmelos L. Correa (Bael)}

It is believed to be associated with Lord Shiva. The leaves and fruits of bael tree are offered to please Lord Shiva. People offer its leaves 'Bael patra' to "Shivling" as it is considered very auspicious.

All parts of it are used for different healing purposes. Bael fruit is popularly used in diarrhoea, dysentery and gastrointestinal disorders and has digestive and carminative properties (Pandey and Pandey, 2016). The products of bael being highly nutritive and therapeutic are getting popularized in Indian as well as international markets. This tree also has ecological value. Various parts of the scared tree have been also used for its pesticidal properties. Its leaves and seed oil are known to have pesticidal properties. In India, waste land which remains unproductive is exploited with bael cultivation to make it productive and hence helps in upliftment of farmer's economy (Sharma, 1997).

\section{Azadirachta indica A. Juss (Neem)}

It is associated with the Sheetala Mata (Goddess of small pox). It is believed that
Sheetala Mata resides in this tree. Neem tree is regarded as 'one tree pharmacy'. The leaves of neem are used in the treatment of smallpox. It is also used in combating bacterial infections such as acne, boils and ulcers (Deepa et al., 2016). People in India use its twigs to brush their teeth.

The ecological importance of the tree benefits environment. Neem seed pulp is useful for methane gas production. It is also useful as carbohydrate which is rich base for other industrial fermentation. Neem is considered useful in rehabilitating waste lands.

Neem cakes are also widely used in India as fertilizer for sugarcane, vegetable and other cash crops. Many countries have been consistently growing the Neem tree against the global warming (Kumar et al., 2013).

\section{Cocos nucifera L. (Coconut)}

It is also called as 'Sriphal'. It is believed that the fruit of the coconut is offered to deities and it fulfils desire of the devotee. The fruit is symbol of fertility and prosperity. To break a coconut in the beginning of any religious event is considered to be very good.

It has antifungal and antimicrobial properties and used for the treatment of skin and mouth problems such as ring worms, candidiasis, sores, skin burns, sunburns, toothache, sore throat and ulcers.

Coconut water is used as diuretic to improve removal of excess water (Deepa et al., 2016). It is also used to treat kidney stones and stomach acidity. Coconut oil is used to treat scalp and hair problems.

Coconut plantations or farm ecosystems can be used in many ways to reduce $\mathrm{CO}_{2}$ emissions and as a substitution of fossil fuel using biodiesel or biomass from coconut oil. 


\section{Datura stramonium L. (Datura)}

It is sacred and is offered to Lord Shiva. The plant along with its flowers, fruits and leaves are offered on the festival of Mahashivaratri. Datura leaves and seeds are used as hypnotic, antiasthmatic and narcotic. It is also used as herbal medicine for bone setting.

Datura plant produces a characteristic odor that acts as repellent for various insects and pests and can be used to manage the twospotted spider mite (Gaire and Subedi, 2013).

\section{Ficus benghalensis L. (Bargad)}

This is the national tree of India. It is also called Indian or Bengal fig. Bargad tree symbolizes Lord Shiva. It also depicts the Trimurti-Brahma (in roots), Vishnu (in bark), and Shiva (in leaves). The tree symbolizes life and fertility and is therefore worshipped by those who are childless.

Several parts of this tree are used to cure many diseases such as dysentery, diabetes and nervous disorders (Gopukumar and Praseetha, 2015). The bark of tree treats diabetes and can be used as a tonic to maintain body temperature. The roots are used to strengthen teeth and gums by brushing with them. According to ayurveda, it is astringent to bowels. The sap of tree treats skin burning and inflammation.

It is also grown as an ornamental and to provide shade along roads as well as in parks and large gardens. It plays major role in soil conservation (Kumar et al., 2013).

\section{Ficus religiosa L. (Peepal)}

This is one of the most sacred tree and associated with planet Saturn and Jupiter. The worshipping of Peepal tree removes obstacles in marriages and financial problems. It is worshipped by men and women especially on saturday by pouring water and milk on its roots and women tie thread around the trunk of the Peepal tree 108 times for prosperity (Pandey and Pandey, 2016).

It is especially useful for patients suffering from Jaundice. It helps to control the excessive amount of urine. The leaves of Peepal are highly effective in treating heart disorder and are also considered valuable in treatment of various kinds of skin disorders (Deepa et al., 2016). In case of formation of pus, the bandaging of leaves heals the wound faster.

The $\mathrm{CO}_{2}$ capturing capacity of Peepal could be fruitful on climate change in environment. The tree is a good habitat for different birds and insects. Planting Peepal tree on riverbank controls the soil erosion. The tree also ameliorates environmental conditions viz., humidity, light, temperature, and soil nutrient levels under its canopies (Cottee-Jones et al., 2015).

\section{Mangifera indica L. (Aam)}

It plays a sacred role. In Hinduism and Buddhism there is trend of hanging fresh leaves on door. Its dry twigs are used in Hawans and other rituals.

The leaf ash is used to treat cold and cough. Boiled unripe fruit gives relief in diarrhoea and dysentery (Sahu et al., 2016). The bark has homeostatic and anti-rheumatic properties. A tooth powder made from burnt mango leaves relieves toothache. The leaves have hypertensive properties and are capable of treatment of lowering blood pressure and hypertension. It has significant ecological value. Mango tree provides shade, shelter and habitat to many birds and animals. It reduces soil erosion and increases soil productivity (Kumar et al., 2013). 
Table.1 List of sacred plants in five major temples of Bhopal

\begin{tabular}{|c|c|c|c|c|c|c|c|c|}
\hline S. No. & Botanical Name & Local Name & Family & $\mathbf{A}$ & B & C & $\mathbf{D}$ & $\mathbf{E}$ \\
\hline 1 & Aegle marmelos L. & Bael & Rutaceae & - & - & $\sqrt{ }$ & - & $\sqrt{ }$ \\
\hline 2 & Azadirachta indica L. & Neem & Meliaceae & $\sqrt{ }$ & $\sqrt{ }$ & $\sqrt{ }$ & $\sqrt{ }$ & $\sqrt{ }$ \\
\hline 3 & Cocos nucifera L. & Sriphal & Arecaceae & - & - & $\sqrt{ }$ & - & $\sqrt{ }$ \\
\hline 4 & Datura stramonium L. & Datura & Solanaceae & - & - & - & - & $\sqrt{ }$ \\
\hline 5 & Ficus benghalensis L. & Bargad & Moraceae & - & - & - & - & $\sqrt{ }$ \\
\hline 6 & Ficus religiosa L. & Peepal & Moraceae & $\sqrt{ }$ & $\sqrt{ }$ & $\sqrt{ }$ & $\sqrt{ }$ & $\sqrt{ }$ \\
\hline 7 & Magnifera indica L. & Aam & Anacardiaceae & - & - & - & $\sqrt{ }$ & $\sqrt{ }$ \\
\hline 8 & Musa paradisiacal L. & Kela & Moraceae & $\sqrt{ }$ & $\sqrt{ }$ & $\sqrt{ }$ & $\sqrt{ }$ & - \\
\hline 9 & $\begin{array}{l}\text { Neolamarckia cadamba } \\
\text { (Roxb.) Bosser }\end{array}$ & Kadambb & Rubiaceae & - & - & - & - & $\sqrt{ }$ \\
\hline 10 & Ocimum tenuiflorum $\mathrm{L}$. & Tulsi & Lamiaceae & $\sqrt{ }$ & $\sqrt{ }$ & $\sqrt{ }$ & $\sqrt{ }$ & $\sqrt{ }$ \\
\hline 11 & Phyllanthus emblica L. & Amla & Plantae & $\sqrt{ }$ & - & $\sqrt{ }$ & $\sqrt{ }$ & $\sqrt{ }$ \\
\hline 12 & Santalum album L. & Chandan & Santalaceae & $\sqrt{ }$ & - & - & - & - \\
\hline \multirow[t]{2}{*}{13} & Saraca asoca (Roxb.) Willd. & Ashok & Caesalpiniaceae & - & - & $\sqrt{ }$ & $\sqrt{ }$ & $\sqrt{ }$ \\
\hline & & Total & & 6 & 4 & 8 & 7 & 11 \\
\hline
\end{tabular}

A. Panchdev Durga Temple B. Hanuman Chamatkari Temple C. Birla Temple D. Gayatri Temple E. Gufa Temple

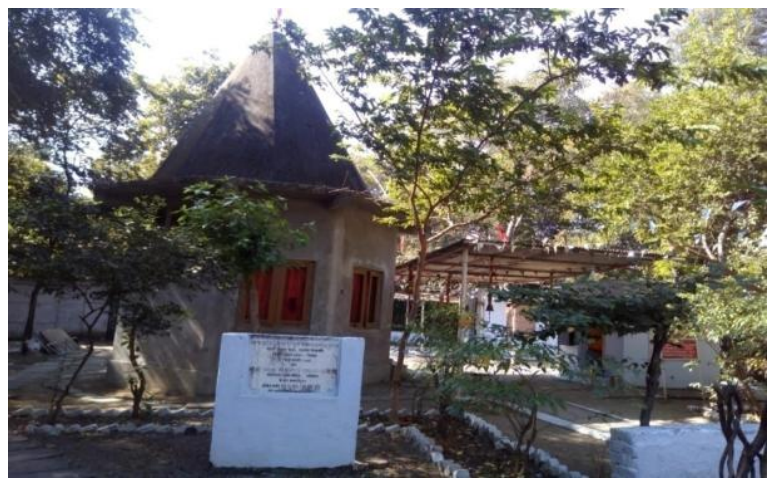

1 Panchdev Durga Temple

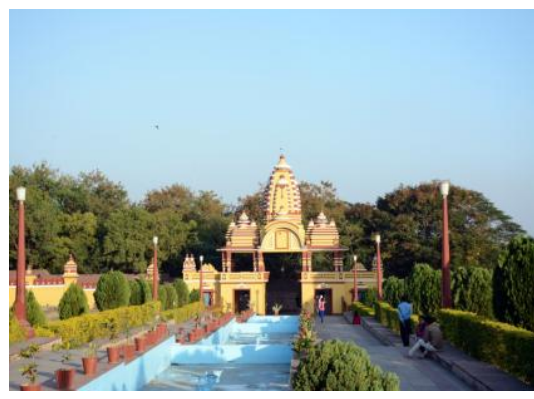

3

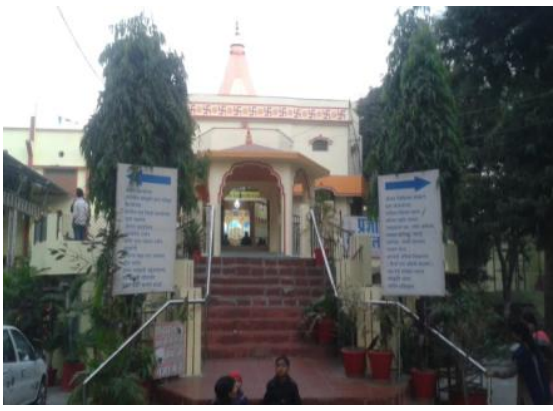

4 Gayatri Temple

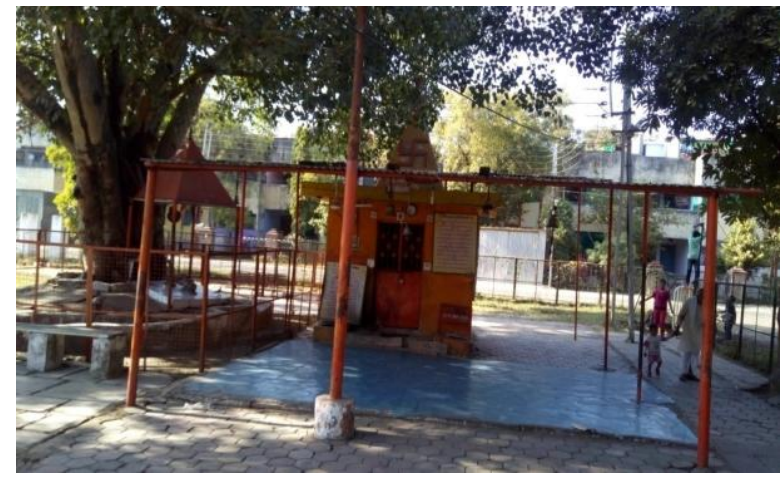

2. Hanuman Chamatkari Temple

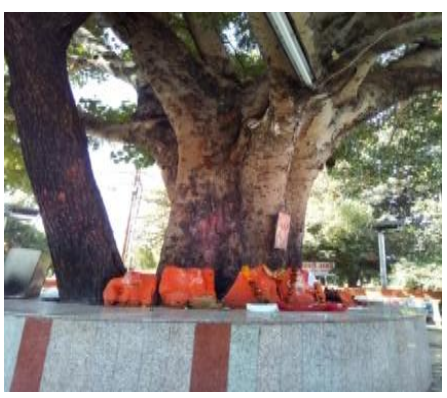

5 Gufa Temple 


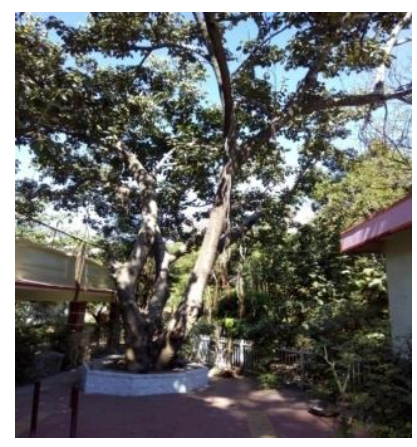

1 Ficus benghalensis in Guffa Temple

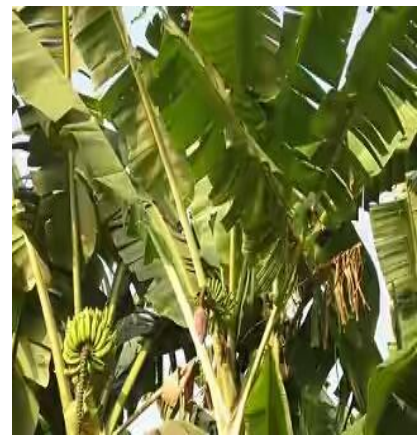

2 Musa paradisiaca at Gayatri temple

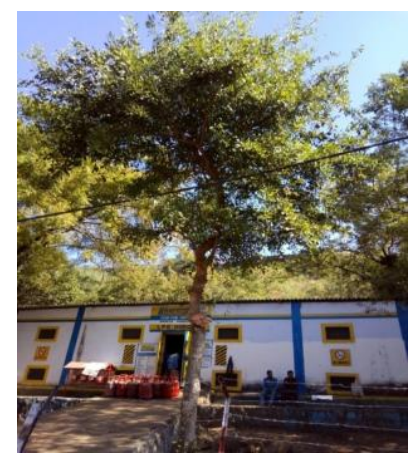

3 Aegle marmelos in Guffa Temple
Musa paradisiaca L. (Kela)

This is a very pious tree and represents Lord Vishnu and Brihaspati. In Hindu mythology it is believed that worshipping the tree with flowers and fruits will bring prosperity in one's family.

The fruit has a mild laxative property. It is used as a remedy of constipation. It is also helpful in curing weakness, diarrhoea and dysentery (Pandey and Pandey, 2016). Its leaves are used as platter for serving food. It also contributes to the structural diversification of the agroforests that helps for creating habitat for local fauna and flora (Mapongmetsem et al., 2012).

\section{Neolamarckia cadamba (Roxb.) Bosser (Kadamb)}

Kadamb tree is regarded highly religious and cultural in India being sacred to the Lord Krishna.

The dried bark is used to relieve fever and used as tonic. An extract of its leaves serves as a mouth gargle.

It helps in the reforestation. The tree is also used for the soil reclamation. It sheds large amounts of leaf which on decomposition improves physicochemical properties of the soil under its canopy.

\section{Ocimum tenuiflorum L. (Tulsi)}

Tulsi is the most holy sacred plant growing in yards in almost all Indian houses and every temple as a symbol of peace and prosperity. It is worshipped as Goddess Lakshmi (wife of Lord Vishnu). Tulsi is worshipped daily due to a belief that it wards off the evil spirits from home.

It has great medicinal value to mankind. Its leaves give relief in stress and cold. It enhances blood circulation and also sharpens the memory. It is used for curing bronchitis, cough, cold, asthma, flu, and emphysema.

Tulsi plant enriches atmosphere through its divine fragrance and purifies air hence also known as 'Queen of Herbs' (Kumari and Charantimath, 2011). It gives out oxygen along with the formation of nascent oxygen which absorbs harmful gases like carbon monoxide, carbon dioxide and sulphur dioxide from the environment.

\section{Phyllanthus emblica L. (Amla)}

It is the first tree to be created in the universe according to Hindu mythology. It is worshiped on Amla navami and Amalaka Ekadashi. The worshiping of Amla tree brings unlimited punya (fortune) to the devotee. All parts of the plant have medicinal value. The fruit has been used in Ayurveda for the 
treatment of diarrohea, jaundice, and inflammation. It rejuvenates male reproductive system and also increases the fertility in women. Its various parts show antidiabetic, antibacterial, antioxidant and gastroprotective properties (Krishnaveni and Mirunalini, 2010). It is one of the important content of 'Triphla' which is used for making digestive powders.

Amla is not only a source of nutrients and medicine, its cultivation is also highly remunerative for the farmers having marginal land. Traditionally, Amla has been a crop of forest or household and during the last few decades, there has been unprecedented expansion in the area under Amla cultivation across the country, utilizing the wasteland. This has resulted in efficient utilization of resources leading to better income to farmers, nutritional security coupled with enhanced employment and rehabilitation of wastelands (Shah, 2017).

\section{Santalum album L. (Chandan)}

The tree itself is not worshipped but its wood, which is very fragrant, is used in worship which gives a lot of religious significance. The heartwood of tree is used in religious pujas to make "Chandan paste", these pastes are applied to the forehead of Gods and then of the worshipers. The sandal incense sticks are offered during prayers. It has antiseptic and anti-inflammatory properties. Sandalwood syrup relieves coughs and sore throat. It is also beneficial in the treatment of digestive disorders. Sandalwood paste heals skin infections. Sandalwood oil is widely used in the cosmetic industry.

In India, the tree is considered for agroforestry practices. It is sometimes grown as an ornamental and as a low-branching wind-break, while its leaves provide green manure.

\section{Saraca asoca (Roxb.) Wild. (Ashok)}

Ashok (Sanskrit) means without grief or the one who gives no grief. Kama Deva is associated with Ashok tree.
The leaves, flowers and bark are used to cure piles and bleeding caused due to piles and also used for purification of blood. The bark, seeds and flowers of the tree are helpful in preparing tonics and capsules to cure various gynaecological problems. The powder made from its seed cures kidney stones and the paste of the seed is used for urine retention. The ash cures rheumatoid arthritis and joint pain.

It helps in controlling air pollution. The intercropping system performs better when grown as a mixed crop with perennial trees like coconut, which provide partial shade to the crop while intercropping with herbs and medicinal plants is also done for better economic returns (Kumar et al., 2013). During the present study it was observed that the religious activities share a close relationship with plants found in temples and household. Sacred plants are worshiped in various religious activities and used in traditional medicinal practices. The majority of plants or trees are accepted as sacred in different religion and hence worshiped. The fallen parts of the sacred trees are used but the cutting of sacred trees is totally prohibited. Such sacred practices play an important role in the conservation of biodiversity and natural habitat of animals. The plants that are on the verge of extinction are also safely preserved in temples. The religious ceremonies and rituals act as a protective factor for saving floral diversity. It preserves and promotes the conservation of biodiversity and nature. The study elucidates that religious activities associated with sacred plants enhance the protection and conservation of the biodiversity.

\section{References}

Bajpai, O., Pandey, J. and Chaudhary, L.B. 2016. Ethnomedicinal uses of tree species by Tharu tribes in the Himalayan Terai region of India. Research Journal of Medicinal Plant, 10 (1):19-41.

Bhatla, N., Mukherjee, T. and Singh, G. 1984. Plants: Traditional worshipping. Indian Journal of History of Science, 19 (1):3742. 
Cottee-Jones, H.E.W., Bajpai, O, Chaudhary, L.B. and Whittaker, R.J. 2015. Isolated Ficus trees deliver dual conservation and development benefits in a rural landscape. Ambio, 44(7): 678-684.

Deepa, M.R., Sheema Dharmapal, P. and Udayan, P.S. 2016. Floristic diversities and medicinal importance of selected sacred groves in Thrissur district, Kerala. Tropical Plant Research, 3(1): 230-242.

Gaire, B.P. and Subedi, L. 2013. A review on the pharmacological and toxicological aspects of Datura stramonium L. Journal of Integrative Medicine, 11 (2): 73-79.

Gopukumar, S.T. and Praseetha, P.K. 2015. Ficus benghalensis Linn.-The sacred Indian medicinal tree with potent pharmacological remedies. International Journal of Pharmaceutical Sciences Review and Research, 32(1): 223-227.

Krishnaveni, M. and Mirunalini, S. 2010. Therapeutic potential of Phyllanthus emblica (amla): the ayurvedic wonder. Journal of Basic and Clinical Physiology and Pharmacology, 21(1):93-105.

Kumar, S.R., Arumugam, T., Anandakumar, C.R., Balakrishnan, S. and Rajavel, D.S. 2013. Use of plant species in controlling environmental pollution- A review. Bulletin of Environment, Pharmacology and Life Sciences, 2 (2):52- 63.

Kumari, D.B.S. and Charantimath, A. 2011. Sacred plants-their role in religion and uses in health care system of Savangere district. The Socioscan, 3(1and2):1-4.

Lasco, R.D. 2002. Forest carbon budgets in
Southeast Asia following harvesting and land cover change. Science in China, 45:55-64.

Mapongmetsem, P.M., Nkongmeneck, B.A. and Gubbuk, H. 2012. Socioeconomic importance of the Banana tree (Musa Spp.) in the Guinean Highland Savannah Agroforests. The Scientific World Journal, 2012:1-8.

Pandey, D. and Pandey, V.C. 2016. Sacred plants from ancient to modern era: Traditional worshipping towards plants conservation. Tropical Plant Research, 3(1):136-141.

Sahu, P.K., Kumari, A., Sao, S., Singh, M. and Pandey, P. 2013. Sacred plants and their ethno-botanical importance in central India: A mini review. International Journal of Pharmacy and Life Sciences, 4(8): 2910-2914.

Shah, N.C. 2017. Phyllanthus emblica (Emblica officinalis): An important medicinal and commercial fruit of India-Part IV. Life Science Research, 1(10):14-23.

Sharma, V. K. 1997. Wasteland Horticulture APH Pub, New Delhi.

Sivalingam, D., Rajendran, R. and Anbarasan, K. 2016. Studies on sacred trees of big temples in Cuddalore district, Tamil Nadu, India. International Journal of Environmental Sciences, 6 (6):995-1005.

Truyen, D.M., Mansor, M. and Ruddin, A.S. 2015. A note on aroids ethnobotany in Hau River, Vietnam. Tropical Plant Research, 2(1): 58-63.

\section{How to cite this article:}

Aadil Mir, Vipin Vyas, Pradeep Shrivastava, Abhilasha Bhawsar and Manzoor Ahmad Bhat. 2018. Ecological and Ethnomedicinal Values of Sacred Plants in Some Major Temples of Bhopal, India. Int.J.Curr.Microbiol.App.Sci. 7(01): 1630-1637. doi: https://doi.org/10.20546/ijcmas.2018.701.198 